\title{
Vocal Cord Hemangioma: A Common Tumor in an Unusual Localization. A Case Report with Short Review of Literature
}

\author{
Eliana Piombino $^{1} \cdot$ Giuseppe Broggi $^{2}\left(\right.$ Calogero Grillo $^{3} \cdot$ Antonio Bonanno $^{3} \cdot$ \\ Salvatore Cocuzza $^{3} \cdot$ Ignazio La Mantia $^{3} \cdot$ Rosario Caltabiano $^{2}$
}

Received: 17 August 2021 / Accepted: 26 September 2021 / Published online: 4 October 2021

(C) The Author(s) 2021

\begin{abstract}
Laryngeal adult-type hemangiomas are very rare lesions, more frequent in men, whose optimal treatment consists of microlaryngoscopical excision. We herein report a case of larynx cavernous hemangioma in a 64-year-old woman with hoarseness for about six months. Histologically, the tumor was composed of multiple vessels embedded in an edematous stroma.
\end{abstract}

Keywords Vocal cord Hemangioma - Case report . Review

\section{Introduction}

According to the 2017 World Health Organization (WHO) Classification of Head and Neck Tumors, epithelial tumors are the most frequent laryngeal neoplasms [1]. Non-epithelial lesions are much rarer [2] and include entities such as chondrosarcoma, Kaposi sarcoma, synovial sarcoma, granular cell tumor, myofibroblastic sarcoma, schwannoma, chondroma, ossifying fibromyxoid tumor and hemangioma [3]. Particularly, laryngeal hemangiomas are typically classified into adult and juvenile forms. Adult ones are very rare with only 6 cases reported in literature to

Giuseppe Broggi

giuseppe.broggi@gmail.com

1 Department of Experimental Oncology, Mediterranean Institute of Oncology (IOM), 95029 Catania, Italy

2 Department G.F. Ingrassia, Section of Anatomic Pathology, University of Catania, Santa Sofia Street 87, 95123 Catania, Italy

3 Department G.F. Ingrassia, Section of E.N.T, University of Catania, Santa Sofia Street 87, 95123 Catania, Italy date, occurring more frequently in men and in the histological form of cavernous hemangioma [4, 5] (Table 1). The most common involved sites are epiglottis, aryepiglottic folds, arytenoids and false and true vocal cords [6]. We herein describe the seventh case of vocal cord cavernous hemangioma in a 64-year-old woman.

\section{Case Report}

A 64 years old female presented to the "E.N.T. Section" of University Polyclinic of Catania with a history of hoarseness for about six months. The patient reported no history for neoplastic diseases nor smoking habit. Direct laryngoscopic examination showed a supracordal reddish nodular mass without ulceration of the overlying mucosa, of about $4 \mathrm{~cm}$ in its maximum diameter (Fig. 1). The lesion was excised using a microlaryngoscopic approach. Gross examination of surgical specimen revealed a nodular mass, soft in consistency; the cut surface of the mass showed a whitish neoplasm with multiple brownish spots. Histologically, at low magnification, the tumor consisted of a proliferation of vascular structures embedded in an edematous stroma (Fig. 2). At higher magnification, vessels were variable in size and lined by endothelial cells; vascular wall thickness was also variable, ranging from thick-walled vessels to thin-walled capillary-like ones (Fig. 2-insert).

Smooth muscle bundles embedded within the edematous matrix were also found. Necrosis, mitoses, and nuclear pleomorphism were absent. Immunohistochemically, the endothelial cells were positive for ERG, CD31 and CD34. Based on both morphological and immunohistochemical features the diagnosis of cavernous hemangioma of vocal cord was rendered. 
Table 1 Clinico-pathological features of previously reported vocal cord hemangiomas

\begin{tabular}{|c|c|c|c|c|}
\hline Authors & $\begin{array}{l}\text { Age } \\
\text { (years)/sex }\end{array}$ & Clinical history & Tumor site & $\begin{array}{l}\text { Pathologic } \\
\text { findings }\end{array}$ \\
\hline $\begin{array}{l}\text { Kazikdas } \\
\text { et al. [4] }\end{array}$ & $37 / \mathrm{M}$ & Hemoptysis & $\mathrm{R}$ vocal fold & $\begin{array}{l}\text { Capillary } \\
\text { hemangioma }\end{array}$ \\
\hline Kiho et al. [5] & $42 / \mathrm{M}$ & Collapse holding his throat & $\begin{array}{l}\text { Submucosa of the larynx, the base of the tongue, the } \\
\text { entire epiglottis }\end{array}$ & $\begin{array}{l}\text { Cavernous } \\
\text { hemangioma }\end{array}$ \\
\hline Sari et al. [6] & $45 / \mathrm{M}$ & Hoarseness for 10 years & L side of the vocal cord & $\begin{array}{l}\text { Cavernous } \\
\text { hemangioma }\end{array}$ \\
\hline $\begin{array}{l}\text { Prasad et al. } \\
\quad[7]\end{array}$ & $35 / \mathrm{F}$ & $\begin{array}{l}\text { Hoarseness for six months and noisy } \\
\text { respiration }\end{array}$ & $\mathrm{R}$ vocal cord & $\begin{array}{l}\text { Cavernous } \\
\text { hemangioma }\end{array}$ \\
\hline Egeli et al. [8] & $15 / \mathrm{M}$ & Hoarseness for 2 years & L vocal cord & $\begin{array}{l}\text { Capillary } \\
\text { hemangioma }\end{array}$ \\
\hline $\begin{array}{l}\text { Yilmaz et al. } \\
\text { [9] }\end{array}$ & $41 \mathrm{M}$ & Hoarseness for 2 months & $\begin{array}{l}\text { Anterior commissure to the vocal process of the left } \\
\text { arytenoid }\end{array}$ & $\begin{array}{l}\text { Cavernous } \\
\text { hemangioma }\end{array}$ \\
\hline Present case & $64 / \mathrm{F}$ & Hoarseness & L vocal cord & $\begin{array}{l}\text { Cavernous } \\
\text { hemangioma }\end{array}$ \\
\hline
\end{tabular}

$M$ male, $F$ female, $R$ right, $L$ left

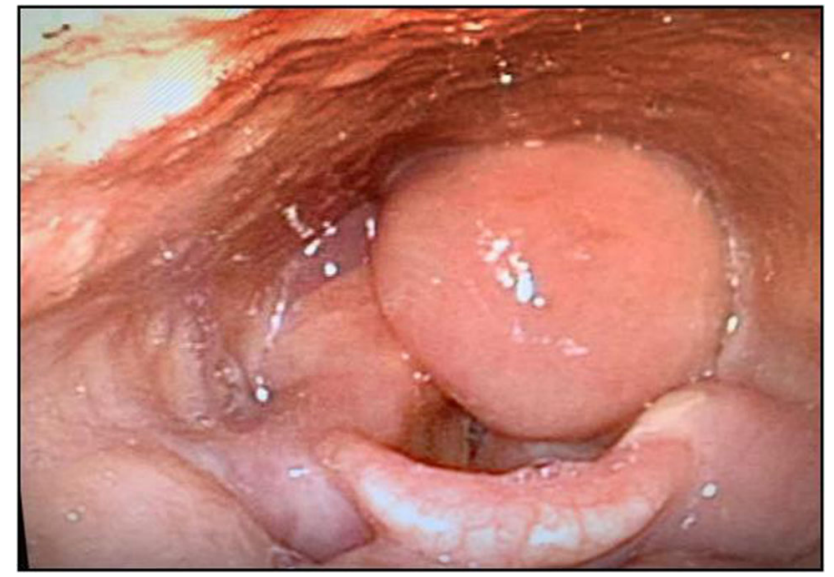

Fig. 1 Microlaryngoscopic examination. Direct laryngoscopy showed a supracordal reddish nodular mass with no ulceration of the overlying mucosa

\section{Discussion}

Laryngeal hemangiomas are typically classified into adult and juvenile forms $[4,5]$. The formers are quite uncommon and often associated to smoking [1]. In our case, patient had no history of cigarette smoking, alcohol abuse or chronic traumatism from prolonged intubation. Hemangiomas are the most frequent benign vascular tumors of soft tissues. Histologically, in this specific anatomic site capillary and cavernous forms of hemangiomas may be encountered [7-9]. Cavernous hemangiomas are more frequent and characterized by thin-walled vascular spaces, larger than the capillary type. A variable proportion of fat tissue or smooth muscle bundles mixed with vascular proliferation may be found. The clinical presentation

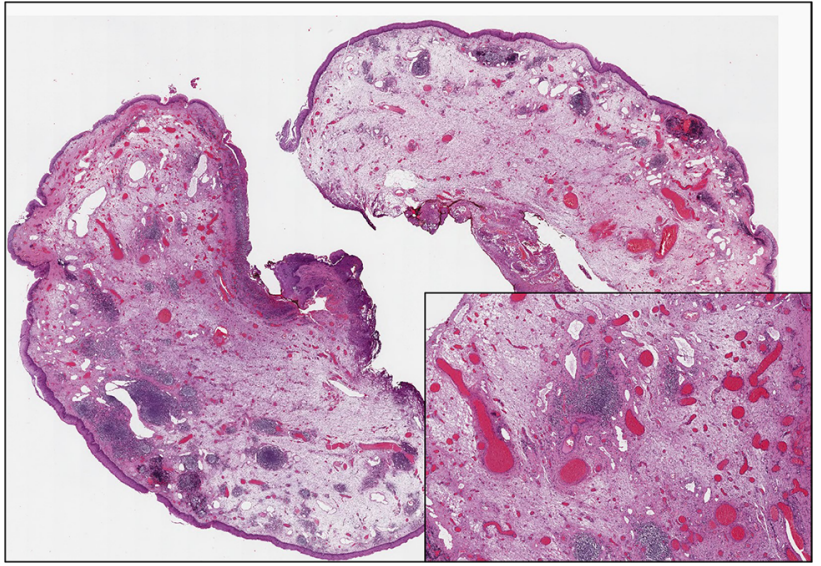

Fig. 2 Histological examination. Low magnification showing a tumor mass composed of multiple vascular structures embedded in an edematous stroma, underlying the squamous epithelium of the laryngeal mucosa; note the variably sized-blood vessels with wall thickness ranging from thick to thin (insert) (hematoxylin and eosin; original magnifications $25 \times$ and $100 \times$, respectively)

consists of phonation disorders or obstructive symptoms, largely depending on the size of the lesion. There are no standardized protocols for vocal cord hemangiomas [9]. The treatment choice of these lesions is affected by the size and age of the patient [8]; adult forms, while not regressing spontaneously, show no tendency to malignant transformation. Accordingly, these patients should only undergo follow-up until bleeding or difficulty breathing occur [10]. Microlaryngoscopical excision is used for treatment. The site causes a difficulty in the complete excision of the neoplasm with a greater risk of recurrence and resumption of the symptoms over time; in addition, vocal fold scar caused by the removal of the tumor may result in 
dysphonia. The use of CO2-laser therapy could be considered in small lesions as it reduces the risk of bleeding [11]; however, using this treatment, we cannot obtain useful material for histological examination.

More invasive treatments, such as thyrotomy, lateral pharyngotomy and transient tracheotomy, can be performed when dealing with larger lesions, which are more likely to be at risk of bleeding during minimally invasive procedures. Steroids and radiation therapy can also be used in case of large-sized tumors to improve obstructive symptoms, but often the results obtained are transient $[8,9]$.

The present paper emphasizes the concept that hemangioma, especially in the adult form, is an unusual but existing laryngeal neoplasm; accordingly, due to its benign clinical behaviour and its different management compared to the most common epithelial neoplasms, it should be always included in the clinical and histopathological differential diagnosis of laryngeal masses.

Authors' Contributions All authors contributed to the study conception and design. The first draft of the manuscript was written by Eliana Piombino and all authors commented on previous versions of the manuscript. All authors read and approved the final manuscript.

Funding Open access funding provided by Università degli Studi di Catania within the CRUI-CARE Agreement. No funds, grants, or other support was received.

Availability of Data and Materials All data and materials of the study are available upon request to the corresponding author.

\section{Declarations}

Conflicts of Interest The authors declare that they have no conflict of interest.

Ethics Approval This is a Case Report study. The Catania 1 Ethics Committee has confirmed that no ethical approval is required.

Informed Consent Informed consent was obtained from all individual participants included in the study.

Consent for Publication The participant has consented to the submission of the case report to the journal.

Open Access This article is licensed under a Creative Commons Attribution 4.0 International License, which permits use, sharing, adaptation, distribution and reproduction in any medium or format, as long as you give appropriate credit to the original author(s) and the source, provide a link to the Creative Commons licence, and indicate if changes were made. The images or other third party material in this article are included in the article's Creative Commons licence, unless indicated otherwise in a credit line to the material. If material is not included in the article's Creative Commons licence and your intended use is not permitted by statutory regulation or exceeds the permitted use, you will need to obtain permission directly from the copyright holder. To view a copy of this licence, visit http://creativecommons.org/licenses/by/4.0/.

\section{References}

1. Slootweg PJ, Grandis JR (2017) Tumours of the hypopharynx, larynx, trachea and parapharyngeal space. In: WHO classification of head and neck tumours, 4th edn., vol. 9 , p. 81

2. Saraydaroglu O, Narter S, Ozsen M et al (2019) Non-epithelial tumors of the larynx: case series of 12 years. Eur Arch Otorhinolaryngol https://doi.org/10.1007/s00405-019-05527-0

3. Karatayli-Ozgursoy S, Bishop JA, Hillel AT et al (2016) Nonepithelial tumors of the larynx: a single institution review. Am J Otolaryngol

37:279-285. https://doi.org/10.1016/j.amjoto.2016.01.005

4. Kazikdas KC, Yalcinozan ET, Tinazli R et al (2019) Vocal fold hemangioma. Ear Nose Throat J 98:257-258. https://doi.org/10.1177/0145561319840135

5. Kiho L, Byard RW (2015) Acute fatal upper airway obstruction from an occult cavernous hemangioma of the larynx. J Forensic 60(Suppl 1):S93-S96. https://doi.org/10.1111/1556-4029.12587

6. Sari F, Topdag M, Ozturk M et al (2014) Vocal cord hemangioma: a rare entity. J Craniofac Surg 25:1565. https://doi.org/10.1097/SCS.0000000000000753

7. Prasad SC, Prasad KC, Bhat J (2008) Vocal cord hemangioma. Med J Malays 63:419-420

8. Egeli E, Oghan F, Alper M et al (2005) Unusual case of laryngeal tumor (capillary hemangioma) obturating the larynx. Ann Otolaryngol Chir Cervicofac 122:154-156. https://doi.org/10.1016/s0003-438x(05)82342-4

9. Yılmaz MD, Aktepe F, Altuntaş A (2004) Cavernous hemangioma of the left vocal cord. Eur Arch Otorhinolaryngol 261:310-311. https://doi.org/10.1007/s00405-003-0695-7

10. Powell J, Blouin MM, David M et al (2012) Bleeding in congenital hemangiomas: crusting as clinical predictive sign and usefulness of tranexamic acid. Pediatr Dermatol 29:182-185. https://doi.org/10.1111/j.1525-1470.2011.01517.x

11. Wolfensberger M (1989) CO2-Laserchirurgie in der ORL [CO2laser surgery in otorhinolaryngology]. Schweiz Rundsch Med Prax 78:471-473

Publisher's Note Springer Nature remains neutral with regard to jurisdictional claims in published maps and institutional affiliations. 